\title{
PLOVERS IN LOCKDOWN: AN AUTOETHNOGRAPHIC STUDY ABOUT VALUES IN LEADERSHIP DECISION-MAKING
}

\author{
Bonnie Robinson
}

\section{DISCOVERING PLOVER-TOWN - WALKING INTO A CONFLICT BETWEEN MY VALUES AND MY ACTIONS}

Auckland was two days into Lockdown lite (Covid Level 3)' in August 2020 when my husband came back from supporting our local bakery, a little excitement in his voice as he gave me the news: "There are baby plovers on the wasteland."

My first thought was "Cool" and then "What exactly is a plover?"

I live in a newish subdivision and there are still undeveloped parts. Nature always takes on these unbuilt areas. Grass self-seeds, plants grow green mountains on the builder's rubble, ponds form in the hollows when it rains, and birds start gathering. Pũkekos rule of course, but from time-to-time other birds arrive and try to make this urban outpost home for a while.

The wasteland is our local bit of this green guerrilla resurgence (take back the land!). It is a large flat section next to our small shopping centre and has recently been fenced, which cuts off the shortcut to the bakery, but does not stop the birds, or the cats, since it is a wire fence with wide mesh.

Later that afternoon we go for our lockdown walk. Being good citizens, we keep to places that are local, and this means we know the square meterage of our small suburb incredibly well. The plovers are welcome added interest.

The plovers, it turns out, are a family of six - Mum, Dad and four fluffy chicks. Cute as. The first day I saw them they were at the venturing out from Mum stage. Although they can feed themselves almost from birth, plovers do not develop the ability to fly for three months after they hatch. Mum and Dad keep a careful watch, and Dad did a dive bomb reconnoitre of us as we stood watching. Something eventually spooked them. Mum called and Dad cried, and the chicks shimmied back to Mum and sat under her, completely unable to be seen.

I Covid Level 3 Lockdown in NZ means most workplaces and shops closed, but some takeaways available. 
We carried on with our walk, our Covid-suppressed spirits lifted a bit by the experience of plover watching, the simple wonder of nature, and how some things seem to be innate to all species such as the need to protect the vulnerable young.

And then we started counting cats. As we walked home suddenly it was like the suburb had literally rained cats. They were everywhere. So, we started to worry. Those silly plovers, nesting on open ground, they were surely doomed.

Back at home I looked at my beloved Burmese, $M$, and felt guilty. Moving into this house and getting a pet was a big deal. For years we had lived in housing supplied by my husband's employer. Buying this house meant I could keep a pet for the first time in II years. I have always loved animals, especially cats. I love their grace when they jump, their soft fur, and the fact that in their DNA they know they used to be worshipped as gods. When we moved into our own place, I got two Burmese kittens, Max and M.

I knew when I did this that it was, in fact, wrong. The world does not need more cats. New Zealand and its wild life do not need more cats. I knew about the destruction of our bird and lizard populations due to cats, but I still went and got two cats, because I wanted to feel at home, and I wanted something to nurture. In the end I put what I wanted above the needs of our native species. I went against my values.

To be fair, or maybe just self-justify, I have tried to be a very responsible cat owner. We keep the cats in from dusk to dawn - which is when they catch most of their prey. When Max died, I resisted the temptation to replace him. Cat population down by one. But still, M exists, and from time to time I come home to a murder scene. I just hoped she was too lazy to head to 'Plover-town.'

Each day during lockdown we walked past the plovers and counted chicks. My heart would skip a beat if we could not quickly see four. Once we had, we would head off on our walk, happy again. Then of course, the inevitable happened. One day we could not see four chicks, only two. We waited and waited but could not see them.

When I got home after that walk, I looked at M like she was an accessory to murder. "Stupid cats," I thought. "You are all urban cats here, well fed, no need to hunt." "That's nature," said my husband with annoying equitable logic. "If you have a cat it will hunt, and much, much more than you think. Most of their kill they don't bring home. You know that. You knew that when you got the cats. You made a choice."

I began to plot, or perhaps fantasize, about what I could do to save the plovers. Maybe I could distribute leaflets around the neighbourhood imploring cat owners to keep their cats in at night. "Justice for Plovers!" Maybe I could head down to Plover-town at dusk and dawn and try and scare away the cats. Yeah right. I had to face the grim reality that there was nothing I could do to save the plovers, and that by having a cat I had knowingly contributed to the possibility, perhaps the inevitability, of their demise. 


\section{VALUING PLOVERS OR VALUING CATS: THE PLOVER/CAT DILEMMA}

There is a grace, to be prayed before meals, attributed to the McLeod Clan in Scotland, that goes "And make us worthy of the esteem in which we hold ourselves." Typical Protestant self-depreciation, but also, a valid corrective for leaders who aim to be values-based.

\section{THE PLOVER CAT DILEMMA}

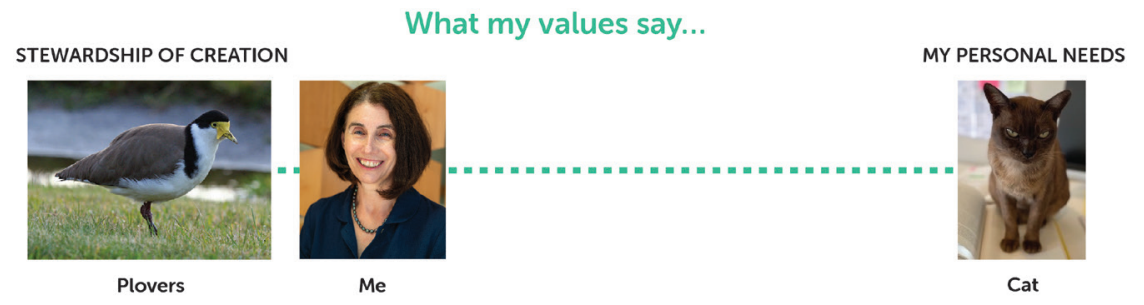

What I did...

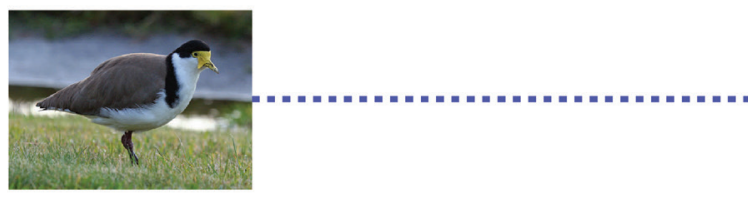

Plovers

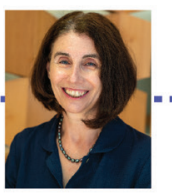

$\mathrm{Me}$

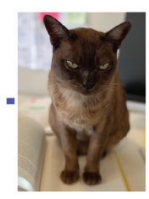

Cat

What the plovers had brought forward for me, in a very practical way, was an ethical dilemma and a concrete example of where my values had not driven my decision making. My values said the stewardship of creation had priority, and in the New Zealand context that meant no cat. Yet even with this knowledge and conscious value, I instead fed my personal emotional needs. Given that my doctorate is examining how leaders can enact values in decision-making, especially the value of social justice, my values failure was disappointing. If I could not even stick to my personal values in my personal life, what hope in my leadership life? And what hope of building systems/processes to support values-based decision-making out of my study?

To help my critical self-reflection, I returned to the literature and to the data from the leadership interviews I had undertaken so far. The literature suggests that leadership is a complex and contradictory mix of the personal and the professional, of your own values, the organisation's values, and simple pragmatism (Berkovich, 20l4). Balancing these is difficult, and in a sense the art that is leadership (DePree, 1989). Much of the literature sees leadership as the task of setting vision, direction, ethics, values, and culture, whereas managing is seen as the task of doing (Paton et al., 2007; Crosby \& Bryson, 2005; Finn \& Jacobson, 2003; Ryan, 2000; Schein, 2010). Some literature, and my experience of practice as a leader, would debate this distinction as artificial - leaders manage, and managers lead - especially in smaller organisations with flatter structures (Mintzberg, 1971; Pervin, 1997). The literature shows that values do require leadership and not just management (Mills \& Spencer, 2005). To make a definitive difference, values can never just be a management tool, they require belief and embodiment. Enacting values, achieving something with them, is therefore as much of a challenge as developing them (Ryan, 2000). I did not enact my values when I got my cats, and the plovers or other wildlife will pay the price. 


\section{RECOGNISING PLOVERS WHEN YOU SEE THEM: HOW DO LEADERS COME TO HAVE AND TO HOLD ON TO VALUES?}

"Why is it so hard to do all the good I want to?" I asked, as my husband and I plodded a little dejectedly around our suburb after yet again seeing only two plover chicks. "I want to do right by creation, I believe that we are stewards, but I seem to constantly make choices that are good for me, and not so much for the planet. Like I am not going to pick up those stray paper face masks un-gloved," I said, looking at a couple of soggy blue masks caught in a hedge, "despite what they'll do to the fish if they get into the sea via the drains."

"So self-critical as usual," said my husband. "At least you think about what is right and wrong, I meet people in my work who have no idea about that. Knowing that there are choices between right and wrong behaviour is a place to start."

He was right of course, but also wrong. In my experience of leadership, knowing right from wrong is not all that is required. Right and wrong decisions are simple - children make them. In leadership, and in life, we are often called on to make what Kidder calls "right versus right" decisions and these are difficult (Kidder, 1995). These take an ability to judge fine nuances. They take values consciousness.

How then do leaders come to have values that can assist them to lead through complex decisions? As we walked during lockdown, I thought about my own experience and the experience of the nine leaders I had interviewed ${ }^{2}$ about social justice leadership. These leaders were focused on shifting whatever context they found themselves in towards justice, equity, and the common good. To achieve these outcomes, all the interviewed leaders identified personal values as a key driver. The organisational values were important but the source of their identity and actions, lay in strongly held, deeply embedded personal values. But where did they get these? Are values-driven leaders born or made?

The literature, in a nature/nurture type debate, is divided as to how leaders come to have strong values. Some suggest that leaders come to leadership with these values inherent in themselves (Mills \& Spencer, 2005), cite religious belief (Ryan, 2000), or point to the ability for life events and social context to embed values (Russell, 200I). Others suggest that values can be nurtured in leaders through training (Finn \& Jacobson, 2003), and the way morality and ethics are discussed within organisations (Dempsey 2008). Kidder argues that morality is innate, and that there are some universal values that transcend time and culture (Kidder, 1995).

The experience of the interviewed leaders is largely in agreement with the literature around the origins of their values, but they described this differently. The leaders identified with these sources:

- Context - geography, economic situation, social situation, and culture all impact on which values leaders hold as most important. The organisational context of leadership is also critical, especially the interaction between leader values and organisation values.

- Family - for most of the interviewed leaders, family background was important because the values they held had been demonstrated in childhood. For two leaders however, it was rejecting some of the values they had been raised with that shaped them most strongly. This rejection was precipitated by a particular event and led them to choose different values for their adult life.

2 Ethics approval for this research was obtained during the Learning Agreement phase of the DProfPrac. Signed consent was obtained from interviewed leaders to allow use of their words but without identifiers. 
- Whakapapa - for Māori leaders that I interviewed, their strong sense of knowing where they come from was a primary source of their values. Values were interwoven with their knowledge of history, ancestry, the example of their ancestors and current kaumatua.

- Education and Training - for some leaders, their profession, training and/or codes of practice impacted significantly on their values. Over time, the professional values come to be identified as personal values.

- Faith/spirituality - for many leaders interviewed faith, in particular Christianity, was core to their values.

- Innately human - some leaders felt that certain values were so innate to being human that perhaps they were not values, as in conscious concepts, but akin to being part of our brains, hard wired.

While the literature and my research might agree that there are many sources of values, my personal plover/cat dilemma suggests that enacting values is not as easy as espousing them. There are multiple pressures on each of us as individuals and as leaders, some of which drive us towards and some away from our values. The leader interviews identified attributes or approaches that supported them to uphold their values.

- Reflective critical thinking

The interviewed leaders discussed the importance of reflecting on their leadership, and how decisions and actions might be impacted by personal and organisational values. This understanding that reflection and critique are important functions of a leader was common to all the leaders interviewed, despite diverse backgrounds and leadership contexts.

- Learning and knowledge

Related to critical thinking, was a leadership commitment to learning and knowledge. Through deliberate learning, formal and informal, leaders sought to refresh their ethical toolbox, tease out assumptions and find new models.

- $\quad$ Letting life impact on practice

Described by most leaders interviewed, and cited within some literature (Finn \& Jacobson, 2003; Ryan, 2000), is the importance of allowing what occurs to change thinking and then practice. There is a sense that the values that drive leaders who seek social good and social justice are both fixed, and fluid. Leaders reflected core beliefs that did not change, but their understanding of them, how they could be enacted, and the priority of one value over another, changed as experiences came to layer understanding and ability to act. Leaders felt the need to find an intersection between values and practicality.

- Meeting real people in real places

A subset of life impacting on practice, but an important one to the leaders, was the influence of meeting people within their own contexts, and how this changed or cemented leaders' values and their commitment to upholding values. People's actual lives, experienced by leaders either directly or indirectly through managing service provision, took theoretical knowledge of values into the arena of praxis.

- Curiosity

Only one leader explicitly used this word but nearly all the leaders expressed the concept - that curiosity was crucial to their values. Curiosity in this context meant a genuine interest in finding out about people and contexts that were unknown, 'other', and, to do this first-hand, not through books or theory. Curiosity for leaders is an innate need to know and to understand before 'judging' or acting. The values arising from the ontological approach of curiosity, seemed to be more strongly held, able to stand up to organisational, societal, or political opposition. 
- " "I know who I am. But it's not about me."

Leaders and the literature indicate that a combination of self-knowledge and selflessness is seen in valuesbased leadership. Servant Leadership (Russell, 2001; Spears, 2010) in particular upholds this model. Developed by Robert Greenleaf in the 1970s (Greenleaf, 2002), aspects of Servant Leadership are referenced in many theories and discussions of moral, ethical, and effective leadership, where the leader has both drive and humility (Collins, 2005). Many of the leaders interviewed indicated that once they knew that the focus of their leadership was not themselves, but always the commons, then the enactment of values was easier, because leadership became focused on mission not personal achievement.

\section{PLOVERS IN THE REAL WORLD - ENACTING VALUES IN LEADERSHIP PRACTICE}

Taking a break from study a few days after thinking about how leaders come to have values, my husband suggests we go by the plovers and see how they are doing. I say no. "I don't want to know. What if there are no chicks left? I can't face it."

"Running away won't change nature," said my husband.

"Yes, but I don't have to see the grim reality of it," I said. As we walked, avoiding Plover-town, I did reflect, "I wonder what Aristotle, Kant and Mills would say about the choice between cats and plovers?"

"OK so that is way too big a question for one walk, and also we need Glen if you want to talk about this," said my husband. Glen is a friend of ours who is a Professor of Moral Philosophy.

"It's just I know from my study that these ethical dilemmas are not new," I said. "They go back centuries and there are loads of erudite books on how to resolve them. But in the moment, when I am at work, I don't have time to remember or invoke all that. And in the moment when I had to choose between getting a cat or not, my emotions won. Ethics always seems easier in theory than in practice."

"Maybe if we'd known about the plovers when we moved in, your decision might have been different," said my husband, "Aren't decisions often contextual?"

"Well, that's one theory," I replied.

The literature is full of theories on how to hold to values and resolve the ethical dilemmas they bring. Some clearly come from a particular branch of moral philosophy, focusing leaders towards Aristotle's focus on character (Covey, 1989; Greenleaf, 2002), Kant's view of right action (Kidder, 1995), Mills' concern with future benefit for the many or a combination of all of these (Collins, 2005; Schein, 2010; Bird \& Waters, 1989). Others focus on methodologies for supporting values-based decisions such as frameworks or questions (Fischer, 2006; Kidder, 1995).

Michael McCuddy tries for a practical middle ground between many of the theories by offering up the concept of self-fullness (McCuddy, 2008.) A mid-point between selfishness, which he views as negative except where survival is required, and self-lessness, which he views as unattainable by most, self-fulness is the simultaneous pursuit of self-interest and the common good. Described by McCuddy as a "both/and moral orientation" selffullness recognises "the need for human beings to make decisions and take actions that reflect both self-interest and service to others" (McCuddy, 2008, p. 4). 


\section{MCCUDDY'S CONCEPT}

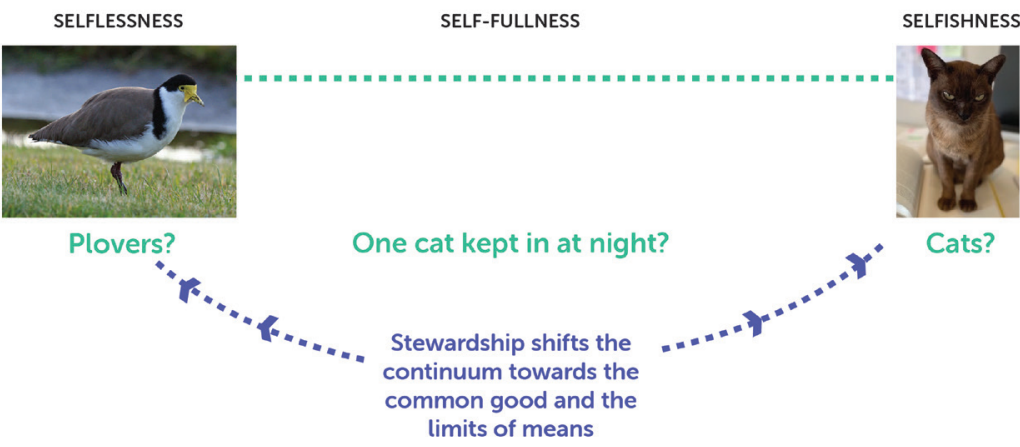

This is of course a noble ideal and, on the surface, a workable solution to the potential conflict between individual and community needs. However, as I pondered my plover/cat dilemma, it felt like this middle ground could be just a moral justification of action that is still primarily orientated to my personal needs. Self-fullness could be an 'almost anything goes' approach because you could manipulate the continuum, until you add in McCuddy's ultimate moral basis for decision making - stewardship, which pushes the continuum strongly towards selflessness. For McCuddy, stewardship "Reflects the wise use, development and appropriate conservation of resources that have been entrusted to the care of human beings... [it is] a protective restraint that humans impose on themselves" (McCuddy, 2008, p. 5). Using stewardship, my dilemma would therefore be more likely to be pushed in favour of the plovers and no cats.

McCuddy's self-fullness is one theory or construct of how to enact values. But as I walked the lock-down walks I thought about what my interviewees had said about what impacted on their ability to use their values in decision-making.

\section{LEADER INTERVIEWEE EXPERIENCE IN PRACTICE}

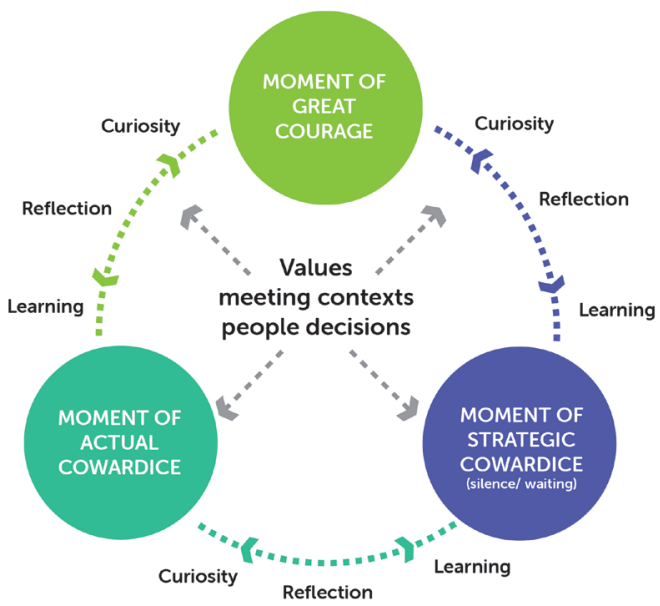


What the leaders described was a continual cycle of action, reflection, and learning, strengthened by curiosity. Leaders' values, personal and organisational, met existing and new contexts, issues, and people, which required decisions to be made, that presented challenges to, or confirmation of values.

In applying their values to these varying contexts, people and decisions, leaders noted at least three general approaches:

- Moments of Great Courage: there were moments when the leaders made decisions and felt that in doing so, they upheld their values - at times in the face of opposition and in situations where there might be a personal or organisational cost.

- Moments of Strategic Cowardice: there were moments when the leaders did not make a values matched decision or when they remained silent. This was deliberate and strategic because they judged that the time was not right. They needed to wait for support or information, so that they had a better chance of being able to achieve a values-based practical outcome.

- Moments of Actual Cowardice: these were moments when the leaders felt they had not acted in accordance with their values. They had gone against their values because of fear, a lack of power or agency, reputational issues, or the need to keep a job.

The diagram is a circle because what leaders described was not a linear process. While they learnt from each experience and courage might be gained, there would still be moments ahead of cowardice, especially strategic cowardice. This therefore reflects McCuddy's framework, where no-one can always live within self-lessness (courage) but nor should they always live with selfishness (cowardice).

\section{FLY LITTLE PLOVERS - IMPLICATIONS FOR RESEARCH AND LEADERSHIP PRACTICE}

Reflecting on the interview findings, and McCuddy's framework, I decided to solve my plover/cat dilemma. I was driven to do so by the inevitable. One day we could not see any chicks at all. Not that day nor any other for the rest of lockdown. I was dejected, and then resolute.

"How are those conversations with the giants of moral philosophy going?" my husband asked.

"I've made up my mind," I said, "When M dies, no more cats. I'll do fostering for the SPCA or the Guide Dog people instead."

"That will take great emotional resolve on your part," said my husband.

"Values seem to take that. That's why I need to do more work out of this whole episode."

So much had arisen out of my plover story, its interaction with my leader interviews and the literature around values in leadership. If I am to make this useful for my own practice and the practice of other values-led leaders, I need to focus on one or two key discoveries.

\section{Curiosity}

The concept of curiosity is worthy of further reflection and research, especially around its relevance for supporting values-led decisions. Curiosity in this context seems to be about more than learning. Some leaders described it as almost a way of living, of approaching the world, and ethical issues. Curiosity denotes an openness to the 'and/and' space, where there are more possibilities than are known, and resolution to issues can be found in the 'we', in the collective space, in the places where people meet. The place of curiosity and how to nurture this in leaders is worthy of further exploration. 
2. Putting 'l' into ethical reflection by leaders

Bird and Waters, in their research on the moral muteness of managers stated:

It is an idealistic misconception to suppose that moral reasons by virtue of their logic alone inspire the feelings of obligation and desire that make people willingly adhere to moral standards. (Bird \& Waters, 1989, p. 81)

My plover journey has shown me that I do not always operate by the logical truth of my values. To get beyond the singularity of logic and become open to plurality, the adoption of narrative methodologies and in particular the first-person story, has been practice-changing for me.

Writing a story in the first person gives transparency, but simultaneously allows for experimentation and the exploration of options. The practice of first-person narrative writing might therefore be a tool to enhance the ability of leaders to make values-based decisions. In writing my story of the plovers, I was prompted to examine deeply my personal values, and why I had failed in this instance to enact them. Beyond logic and rationality, I was able to see the power of emotion and personal need. Using this form of reflection in my practice, | deliberately placed myself in the 'story' of my difficult leadership decisions. Using narrative, I could become different characters and tell the decision story from varied perspectives. Like a $360^{\circ}$ view, story gave greater breadth and depth to my decisions. Given the nuance often required in decision making, this tool might be usefully explored and utilised by leaders in a wide variety of contexts, including the day-to-day leadership we all undertake of our own lives.

\section{PLOVERS VERSUS CATS - THE RESULT}

After giving up hope for the plovers I was out for a post lockdown walk and heard much squawking as I passed the wasteland. Looking around I saw Mum, Dad and two noisy teenagers. Perhaps in the contest between plovers and cats, or values and actions, right now it is a draw. Maybe if values are strengthened by narrative reflection and curiosity, in future the wildlife might win.

Bonnie Robinson is a student of the Doctor of Professional Practice at Capable NZ Otago Polytechnic. Her area of study focusses on support leaders of social justice around values-based decision-making. Bonnie has many years' experience working in the non-profit social service sector. Currently she is the CEO of a non-profit provider of services for vulnerable older people.

Email: Bonnierobinson036@gmail.com

Otago Polytech ethics approval reference number: 824

\section{REFERENCES}

Berkovich, Izhak. (2014). A Socio-Ecological Framework of Social Justice Leadership in Education. Journal of Educational Administration, 52(3): 282-309. https://doi.org/I0.1108/JEA-12-2012-0131

Bird, F. B, \& Waters, James. (1989). The Moral Muteness of Managers. California Management Review, 32(I) (Fall): $73-88$.

Collins, Jim. (2005). Good to Great and the Social Sectors. Jim Collins.

Covey, Stephen M. (1989). The 7 Habits of Highly Effective People. Simon and Schuster.

Crosby, Barbara C., \& Bryson, John M. (2005). A Leadership Framework for Cross-Sector Collaboration. Public Management Review 7(2): |77-20।. 
Dempsey, David. 2008. "The Path to Social Justice Goes through Politics and Economics." Journal of Policy Practice 7 (2-3): 94-105.

DePree, Max. (1989). Leadership Is an Art. Doubleday.

Finn, Janet L., \& Jacobson, Maxine. (2003). Just Practice: Steps toward a New Social Work Paradigm. Journal of Social Work Education, 39(1): 57-78.

Fischer, Marilyn. (2006). The Colour of Ethics. Thoughtful Fundraising: Concepts, Issues and Perspectives, January. https:// ecommons.udayton.edu/phl_fac_pub/I53

Greenleaf, Robert K. (2002). Servant Leadership: A Journey Into the Nature of Legitimate Power and Greatness. Paulist Press.

Kidder, Rushworth. (1995). How Good People Make Tough Choices. Harper.

McCuddy, Michael K. (2008). Fundamental Moral Orientations: Implications for Values-Based Leadership. The Journal of Values-Based Leadership, I (Winter/Spring).

Mills, Ann E., \& Spencer, Edward M. (2005). Values Based Decision Making: A Tool for Achieving the Goals of Healthcare. In Hec Forum, 17:18-32. Springer.

Mintzberg, Henry. 197I. Managerial Work: Analysis from Observation. Management Science, 18(2): B-97. https://doi.org/I0.I287/ mnsc.18.2.B97

Paton, Rob, Mordaunt, Jill, \& Cornforth, Chris. (2007). Beyond Non-profit Management Education: Leadership Development in a Time of Blurred Boundaries and Distributed Learning. Non-profit and Voluntary Sector Quarterly Supplement, 36(no 4): 148S-162S.

Pervin, Aron. (1997). A Conversation with Henry Mintzberg. Family Business Review, 10(2): 185-185.

Russell, Robert F. (200I). The Role of Values in Servant Leadership. Leadership \& Organization Development Journal, 22(2): 76-84. https://doi.org//0.1108/01437730110382631

Ryan, Leo V. (2000). Moral Aspects of Executive Leadership. International Journal of Value-Based Management, 13(2): $109-22$.

Schein, Edgar H. (2010). Organizational Culture and Leadership (4th ed.). Jossey-Bass.

Spears, Larry C. (2010). Servant Leadership and Robert K. Greenleaf's Legacy. In Dirk van Dierendonck \& Kathleen Patterson (Eds.), Servant Leadership: Developments in Theory and Research (pp. II-24). Palgrave Macmillan UK. https:// doi.org/l0.1057/9780230299184_2 